BioLink : Jurnal Biologi Lingkungan, Industri dan Kesehatan, Vol. 6 (1) Agustus (2019)

ISSN: 2356- 458X (print) ISSN: 2550-1305 (online)

BioLink

Jurnal Biologi Lingkungan, Industri, Kesehatan

Available online http://ojs.uma.ac.id/index.php/biolink

\title{
UJI ANTIBAKTERI EKSTRAK BUAH TAKOKAK (SOLANUM TORVUM SWARTZ) TERHADAP PERTUMBUHAN BAKTERI PROPIONIBACTERIUM ACNES
}

\section{ANTIBACTERIAL TEST OF TAKOKAK FRUIT EXTRACT (SOLANUM TORVUM SWARTZ) AGAINST PROPIONIBACTERIUM ACNES BACTERIAL GROWTH}

\author{
Merta Meliana Lajira, I Nyoman Ehrich Lister* \\ Program Studi Pendidikan Dokter, Fakultas Kedokteran, Universitas Prima Indonesia, \\ Indonesia
}

Diterima : 06-02-19; Disetujui : 26-04-19: Diterbitkan : 12-08-19

*Corresponding author: E-mail: Melianalajira@gmail.com

\begin{abstract}
Abstrak
Acne vulgaris merupakan kelainan pada kulit yang ditandai dengan munculnya komedo, papul, pustul, dan nodul yang sering terjadi pada wajah, bahu, dan punggung. Propionibacterium acnes merupakan organisme utama yang memberi kontribusi terhadap terjadinya acne. Salah satu tanaman yang memiliki efek anti bakteri yaitu buah takokak. Penelitian ini bertujuan untuk mengetahui ada tidaknya efek anti bakteri ekstrak buah takokak terhadap pertumbuhan bakteri Propionibacterium acnes. Metode uji yang digunakan adalah metode disk diffusion Diplo. Buah diekstraksikan dengan metode maserasi menggunakan etanol sebagai pelarut kemudian diencerkan menggunakan etanol $96 \%$ pada konsentrasi $25 \%, 50 \%, 75 \%, 100 \%$ sedangkan kontrol positif menggunakan suspensi klindamisin dan kontrol negatifnya aquades. Hasil penelitian menunjukkan bahwa ekstrak buah takokak memiliki efek antibakteri terhadap Propionibacterium acnes dengan rata-rata diameter zona hambat 16,75 mm; 18,3 $\mathrm{mm}$; $18,85 \mathrm{~mm} ; 21,92 \mathrm{~mm}$. Kontrol positif (klindamisin) 37,45; kontrol negatif (aquades) tidak memiliki nilai untuk dapat menghambat bakteri.
\end{abstract}

Kata Kunci: Propionibacterium acnes, antibakteri, takokak

\begin{abstract}
Acne vulgaris is a disorder of the skin characterized by changes in blackheads, papules, pustules, and nodules that often occur on the face, shoulders, and back. Propionibacterium acnes is the main habitat that contributes to acne. One of the plants that have an anti-bacterial effect is takokak fruit. This study aims to study the presence or absence of anti-bacterial effects of takokak fruit extract on the growth of Propionibacterium acne bacteria. The test method used is the Diplo disk diffusion method. The fruit was extracted by maceration method using ethanol as a solvent and then diluted using $96 \%$ ethanol at a concentration of 25\%,50\%,75\%, 100\% while the positive control used a clindamycin suspension and negative control of distilled water. The results showed that takokak fruit extract had an antibacterial effect on Propionibacterium acnes with an average diameter inhibition zone of $16.75 \mathrm{~mm} ; 18.3 \mathrm{~mm} ; 18.85$ mm; $21.92 \mathrm{~mm}$. Positive control (clindamycin) 37,45; negative control (distilled water) has no value to prevent bacteria.
\end{abstract}

Key Words: Propionibacterium acnes, antibacterial, takokak

How to Cite: Lajira, Merta M. dan Lister, I.N. (2019). Uji Antibakteri Ekstrak Buah Takokak (Solanum torvum Swartz) Terhadap Pertumbuhan Bakteri Propionibacterium acnes, BioLink: Jurnal Biologi Lingkungan, Industri dan Kesehatan, Vol.6 (1): Hal. 73-79 
Lajira, Merta M. dan Lister, I.N. Uji Antibakteri Ekstrak Buah Takokak (Solanum torvum Swartz) Terhadap Pertumbuhan Bakteri Propionibacterium acnes

\section{PENDAHULUAN}

Indonesia merupakan salah satu negara yang memiliki keanekaragaman hayati terbesar di dunia, terdapat $30 \mathrm{ribu}$ spesies tanaman berkhasiat sebagai obat yang didapat melalui penelitian ilmiah. Sekitar 180 spesies tanaman obat tersebut yang telah banyak dimanfaatkan oleh industri sebagai obat tradisional Indonesia (Hidayati, et al., 2014). Seiring berjalannya waktu pengetahuan tentang tumbuhan obat tradisional semakin berkembang, kini tanaman obat telah banyak dimanfaatkan (Rahmi, et al. 2015). Takokak (solanum torvum swartz) merupakan tanaman tradisional yang sering digunakan sebagai sayuran, buah-buahan, tanaman hias dan digunakan untuk berbagai keperluan obat (Yousaf, et al., 2013). Beberapa hasil penelitian menyebutkan bahwa tanaman takokak merupakan tanaman yang digunakan dalam pengobatan infeksi yang memiliki aktivitas anti bakteri yang cukup baik. Tanaman Takokak berasal dari kepulauan Antilles, dan penyebaran tumbuhnya sampai ke negara-negara tropika termasuk di Indonesia, tanaman ini tumbuh di daerah Sumatera, Jawa dan sampai di dataran rendah hingga 1 - 1.600 meter di atas permukaan laut, di tempat yang tidak terlalu berair dan agak ternaungi dengan sinar matahari sedang (Sirait, 2009). Terdapat beberapa bagian pada tanaman takokak kaya dengan berbagai kandungan kimia yang sangat bermanfaat bagi kesehatan manusia antara lain: kandungan flavonoid, saponin, alkaloid (Yousaf, et al., 2013).

Propionibacterium acnes merupakan bakteri anaerob yang terdapat pada kulit, tumbuh secara lambat dan bersifat gram positif. Serta berbagai faktor penyebab Acne sangat banyak (multifactorial), antara lain : genetik, endoktrin, faktor makanan, keaktifan dari kelenjar sebasea sendiri, faktor psikis, iklim, infeksi bakteri (Propionibacterium acnes), dan kosmetika. (Sampelan, et al, 2017).

Acne vulgaris adalah penyakit peradangan menahun yang umumnya terjadi pada saat tumbuh remaja dan dapat sembuh dengan sendirinya (Indrawan dan Kusumastuti, 2013). Jerawat dapat timbul apabila saluran permukaan kulit yang mengeluarkan sebum menggumpal dan tersumbat sehingga membentuk komedo yang menonjol dipermukaan kulit, komedo ini akan berkembang menjadi inflamasi apabila terinfeksi oleh bakteri terutama bakteri Propionibacterium acnes. Bakteri ini ikut serta dalam fotogenesis jerawat dengan menghasilkan lipase, yang dapat memecah asam lemak bebas dari lipid kulit. Asam lemak ini dapat menimbulkan radang jaringan dan ikut menyebabkan jerawat kulit. Peradangan tersebut menyebabkan bakteri ini berproliferasi dan memperparah lesi 
inflamasi dengan merangsang produksi sitokin proinflamasi (Sari et al., 2015).

Antibiotik sudah secara luas digunakan sebagai salah satu cara efektif dalam pengobatan Acne vulgaris. Saat ini clindamisin dan erythromycin adalah salah satu antibiotik yang paling sering digunakan dalam pengobatan acne vulgaris. Tetapi penggunaan yang jangka panjang dan luas memunculkan bakteri Propionibacterium acnes resisten terhadap anti bakteri (Seth dan Mishra, 2015 ).

Oleh karena itu untuk mencegah bakteri resisten terhadap antibiotik diperlukan antibakteri alami yang tidak menimbulkan dampak negatif terhadap manusia yaitu dengan memanfaatkan zat aktif pembunuh bakteri yang terdapat dalam tanaman obat seperti pada buah takokak (Utami, 2011).

\section{METODE PENELITIAN}

Penelitian ini merupakan penelitian eksperimental laboratorium untuk melihat hasil pengukuran diameter zona hambat terhadap pertumbuhan bakteri Propionibacterium acnes dengan menggunakan ekstrak buah takokak, berbagai konsentrasi 25\%, 50\%, 75\%, $100 \%$ dan kelompok kontrol positif (klindamisin) dan kontrol negatif (aquades).

Metode pengumpulan data yang dilakukan pada penelitian ini adalah random sampling atau pemilihan sampel secara acak, yaitu semua unit populasi mempunyai kesempatan yang sama untuk dipilih menjadi anggota sampel.

Lampu spiritus, cawan petri, tabung reaksi, beaker glass, rak tabung reaksi, pipet tetes, hotplate, inkubator, kertas cakram, oven, blender, jangka sorong, water bath, aluminium foil, pinset, pengaduk, cotten swab, neraca digital, labu ukur $10 \mathrm{ml}$, batu stirrer, autoclave, kapas, korek api, buah takokak (Solanum torvum swartz), nutrient broth, muller hinton agar, etanol teknis $96 \%$, aquades, cakram antibiotik klindamisin, alkohol $70 \%$, masker steril dan sarung tangan karet.

\section{Pembuatan ekstrak buah takokak}

Buah yang telah di pesan dicuci dengan air yang mengalir hingga bersih, lalu diletakan pada suhu kamar dan tidak boleh terkena sinar matahari, dibiarkan selama seminggu hingga buah mengering dan mudah hancur kemudian di haluskan menggunakan blender. Bubuk buah takokak yang diperoleh di timbang sebanyak 500 gr, kemudian dimasukkan kedalam wadah dengan larutan etanol 96\% sebanyak 5 liter. Kemudian dimaserasi dan diaduk selama 30 menit untuk mencapai kondisi homogen dan diulangi selama 3 hari. Setelah 24 jam larutan difiltrasi atau dipisahkan dengan menggunakan penyaring. Kemudian 
Lajira, Merta M. dan Lister, I.N. Uji Antibakteri Ekstrak Buah Takokak (Solanum torvum Swartz) Terhadap Pertumbuhan Bakteri Propionibacterium acnes

residu penyaringan diangin-anginkan dan tabung reaksi yang telah berisi $10 \mathrm{ml}$ dilakukan maserasi ulang sampai 3 kali. larutan steril. Koloni bakteri dikocok Hasil penyaringan di campur dan sampai koloni halus dan tercampur dipekatkan dengan menggunakan rotary dengan suspensi media hingga terlihat vacuum evaporator dengan suhu $50^{\circ} \mathrm{C}$ adanya kekeruan. Kemudian setarakan sampai ekstrak mengental. dengan standar McFarland (McF) 0,5.

\section{Pembuatan Media Muller Hinton Agar}

Sebanyak 34 g serbuk Muller Hinton Agar ditimbang, kemudian disuspensikan kadalam air suling sebanyak $1000 \mathrm{ml}$, lalu dipanaskan sampai bahan larut sempurna menggunakan hotplate stirrer, lalu disterilkan di dalam autoklaf pada suhu $121^{\circ} \mathrm{C}$ selama 15 menit dengan tekanan $1,5 \mathrm{~kg} / \mathrm{cml}$.

\section{Nutrient Broth (Untuk bakteri)}

Sebanyak 8 g serbuk Nutrient Broth ditimbang, kemudian disuspensikan kadalam air suling sebanyak 1000 ml, lalu dipanaskan sampai bahan larut sempurna, lalu disterilkan di dalam autoklaf pada suhu $121^{\circ} \mathrm{C}$ selama 15 menit.

\section{Pembuatan Suspensi}

\section{Propionibacterium acnes}

Pembuatan suspensi bakteri P.acnes dengan cara dibiakkan pada media MHA selama 24 jam. Kemudian koloni p.acnes diambil satu ose dimasukkan ke dalam

\section{Uji Aktivitas Antibakteri}

Muller Hinton Agar

(MHA)

dituangkan dalam cawan petri steril, lalu tunggu dingin atau sampai agar mengeras kemudian disiapkan cotton swab yang steril lalu dicelupkan kedalam tabung yang berisi koloni bakteri kemudian swab bakteri diatas permukaan agar hingga rata. Letakkan cakram kertas yang telah direndam pada setiap konsentrasi dan diletakkan didalam petri yang telah diswab dengan suhu $37^{\circ} \mathrm{C}$ selama 48 jam kemudian cek hasil. Letakkan kembali cakram kertas yang telah direndam ekstrak dengan variasi konsentrasi dan juga letakkan cakram antibiotik klindamisin pada petri yang telah di swab.

\section{HASIL DAN PEMBAHASAN}

Hasil skrining fitokimia ekstrak buah takokak menunjukkan adanya kandungan alkaloid, saponin, dan flavonoid. Hasil skrining ekstrak buah takokak dapat dilihat pada tabel berikut ini: 
Tabel 1. Hasil Skrining Fitokimia Ekstrak Buah Takokak

\begin{tabular}{ccc}
\hline No & Skrinning & Hasil \\
\hline 1 & Flavanoid & + \\
2 & Alkaloid & + \\
3 & Saponin & + \\
\hline
\end{tabular}

Tabel 2. Hasil Zona Hambar Bakteri Propionibacterium acnes

Diameter zona hambat

\begin{tabular}{ccccccc} 
Percobaan & \multicolumn{5}{c}{ Konsentrasi } & \multicolumn{3}{c}{ Kontrol } \\
& $\mathbf{2 5 \%}$ & $\mathbf{7 5 \%}$ & $\mathbf{5 0 \%}$ & $\mathbf{1 0 0 \%}$ & $\begin{array}{c}\text { (+) } \\
\text { klindamisin }\end{array}$ & $\begin{array}{c}\text { (-) } \\
\text { Aquades }\end{array}$ \\
\hline I & 16,1 & 18,1 & 18,6 & 21,64 & & \\
II & 17,1 & 18,5 & 19,1 & 22,2 & 37,45 & 0 \\
Rata-rata & 16,75 & 18,3 & 18,85 & 21,92 & & \\
\hline
\end{tabular}

Berdasarkan tabel diatas

Zona hambat adalah zona bening

menunjukkan bahwa hasil penelitian yang yang terdapat disekitar media yang telah

dilakukan dengan menggunakan ekstrak diinokulasi bakteri. Aktivitas anti bakteri buah takokak (Solanum torvum swartz) yang berupa zona bening ditimbulkan dari dengan pelarut etanol sebagai antibakteri pemberian ekstrak buah takokak terhadap terhadap bakteri Propionibacterium acnes bakteri Propionibacterium acnes yang dengan konsentrasi 25\%, 50\%, 75\%, disebabkan adanya kandungan senyawa$100 \%$ dengan rata-rata diameter zona senyawa kimia yang terdapat didalamnya. hambat dari pengulangan sebanyak 2 kali, Senyawa kimia tersebut yaitu, flavonoid, menggunakan 2 petri dengan konsentrasi alkaloid dan saponin yang memiliki yang sama yaitu konsentrasi $25 \%$ aktivitas sebagai anti bakteri.

$(16,75 \mathrm{~mm}), \quad 50 \% \quad(18,3 \mathrm{~mm}), \quad 75 \%$

Kandungan flavonoid yang terdapat $(18,85 \mathrm{~mm}), 100 \% \quad(21,92 \mathrm{~mm})$. Ekstrak pada tanaman dapat digunakan sebagai buah takokak dengan kontrol positif antibakteri karena dapat mendenaturasi $(37,45)$ dan kontrol negatif (0) protein sel bakteri dan menggangu membentuk zona hambat.

Penelitian ini merupakan uji aktivitas transpeptidase peptidoglikan eksperimental laboratorium guna mengetahui ada tidaknya efektivitas daya hambat ektrak buah takokak terhadap bakteri Propionibacterum acnes. sehingga pembentukan dinding sel terganggu dan menyebabkan lisis. Saponin menghambat dan membunuh mikroba dengan cara berinteraksi dengan membran sterol sehingga dapat menekan pertumbuhan bakteri. Alkaloid 
Lajira, Merta M. dan Lister, I.N. Uji Antibakteri Ekstrak Buah Takokak (Solanum torvum Swartz) Terhadap Pertumbuhan Bakteri Propionibacterium acnes

menggangu komponen penyusun menghambat pertumbuhan bakteri

peptidoglikan pada sel bakteri.

Berdasarkan skrining fitokimia, ekstrak buah takokak mengandung senyawa-senyawa antibakteri.

Berdasarkan rata-rata hasil zona hambat pada konsentrasi 25\%, 50\%, 75\%, menunjukkan efektivitas sedang sedangkan pada konsentrasi 100\% menunjukkan efektivitas kuat. Adanya daya hambat membuktikan bahwa ekstrak buah takokak memiliki efektivitas menghambat pertumbuhan bakteri

\section{Propionibacterium acnes.}

Dari hasil uji antibakteri ekstrak buah takokak terhadap pertumbuhan bakteri Propionibacterium acnes menunjukan bahwa penelitian yang dilakukan oleh (Rokhmawati et all, 2014) dengan penelitian daya antibakteri ekstrak buah takokak terhadap pertumbuhan Streptococcus mutans bahwa kandungan yang terdapat pada buah takokak dapat menghambat pertumbuhan pada bakteri. Pada penelitian ini terdapat beberapa hambatan yaitu : keterbatasan dalam pembuatan ekstrak serta mudahnya kontaminasi cakram antibiotik setelah dibuka beberapa hari sebelum penggunaan.

\section{SIMPULAN}

Berdasarkan hasil penelitian, dapat disimpulkan bahwa ekstrak Buah Takokak (Solanum torvum Swartz) mampu
Propionibacterium acnes.

\section{UCAPAN TERIMA KASIH}

Penulis mengucapkan terimakasih kepada I Nyoman Ehrich lister selaku dosen pembimbing yang sudah membantu mengarahkan selama penelitian.

\section{DAFTAR PUSTAKA}

Hidayati, N. L. D. and Nofianti, T. (2014) 'Penelusuran Potensi Antifertilitas Buah Takokak (Solanum torvum Swartz) melalui Skrining Fitokimia dan Pengaruhnya terhadap Siklus Estrus Tikus Putih (Rattus norvegicus)', 11(1), pp. 94-103.

Indrawan, N. and Kusumastuti, C. (2013) 'Hubungan Asupan lemak Jenuh Dengan kejadian Acne vulgaris', 2, pp. 578-584.

Rahmi, A. et al. (2015) 'Uji Aktivitas Antibakteri Ekstrak Daun Beluntas Terhadap Propionibacterium acnes Penyebab Jerawat', IX(1), pp. 141-161.

Rokhmawati, A., Gunadi, A., \& Fatmawati, D. W. A. (2014). Daya Antibakteri Ekstrak Buah Takokak (Solanum torvum Swartz) terhadap Pertumbuhan Streptococcus mutans. Artikel Ilmiah Hasil Penelitian Mahasiswa, 1-7.https://doi.org/10.1111/j.15231739.2012.01959.X

Sari, I. P., Wibowo, M. A. and Arreneuz, S. (2015) 'Aktivitas Antibakteri Ekstrak Teripang Butoh Keling (Holothuria leucospilota) dari Pulau lemukutan terhadap Baakteri Propionibacterium acnes dan Staphylococcus Epidermidis', 4(4).

Sampelan, M. G., Pangemanan, D. and Kundre, R. M. (2017) 'Hubungan Timbulnya Acne vulgaris Dengan Tingkat Kecemasan Pada Remaja di SMP 1 Likupang Timur', 5(1).

Sirait, N. (2009). Terong Cepoka (Solanum torvum) Herba yang Berkhasiat sebagai Obat. Penelitian Dan Pengembangan Tanaman Industri, 15(3), 10-12.

Seth, V., \& Mishra, A. (2015). Acne vulgaris management: what's new and what's still true? International Journal of Advances in Medicine,2(1),1.https://doi.org/10.5455/2349 -3933.ijam20150201

Utami, E. R. (2011). Resistensi antibiotik dan rasionalitas terapi. Antibiotika, Resistensi, Dan Rasionalitas Terapi, 1(4), 191. 
https://doi.org/http://dx.doi.org/10.1886o/e lha.vii4.1783

Yousaf, Z., Wang, Y., \& Baydoun, E. (2013). Phytochemistry and pharmacological studies on Solanum torvum Swartz. Journal of Applied Pharmaceutical Science, 3(4), 152-16o.

https://doi.org/10.7324/JAPS.2013.3428 